\title{
Ponto contra ponto: o debate sobre a nacionalização musical no Brasil e o Café
}

Tiago Hermano Breunig ${ }^{7}$ Universidade Federal de Pernambuco tiago.breunig@ufpe.br 


\section{Resumo}

O presente artigo procura analisar as perspectivas envolvidas nos embates entre erudito e vanguarda, de um lado, e popular e folclore, de outro, em torno da politização da arte e da nacionalização musical no Brasil da primeira metade do XX, especialmente a partir de $\mathrm{H}$. J. Koellreutter. Para tanto, confrontamos as perspectivas de autores como T. W. Adorno e Antonio Gramsci, H. J. Koellreutter e Mário de Andrade, recorrendo aos acervos documentais destes para compreender como a musicalização de Café, de Mário de Andrade, por $\mathrm{H}$. J Koellreutter, se inscreve no debate sobre o nacionalismo musical brasileiro.

Palavras-chave: H. J. Koellreutter; Mário de Andrade; folclore; nacionalismo musical.

\section{Abstract}

This article aims to analyze the perspectives involved in the debates between erudite and avant-garde, on the one hand, popular and folklore, on the other, around the politicization of art and nationalization of music in Brazil of the first half of the 20th century, especially from H. J. Koellreutter. Therefore, we compare the perspectives of authors such as T. W. Adorno and Antonio Gramsci, H. J. Koellreutter and Mário de Andrade, resorting to documents of H. J. Koellreutter's and Mário de Andrade's archives to understand how the musicalization of Mário de Andrade's Café, by $\mathrm{H}$. J Koellreutter, is part of the debate on Brazilian musical nationalism.

Keywords: H. J. Koellreutter; Mário de Andrade; folklore; musical nationalism. 
A maioria das pessoas é consciente sobretudo de uma cultura, de um ambiente, de um lar; os exilados são conscientes de pelo menos dois, e essa pluralidade de visão dá lugar a uma consciência que - para utilizar uma expressão da música - é contrapontística...

(James Clifford, 1986)

... somos ainda hoje uns desterrados em nossa terra.

(Sérgio Buarque de Holanda, 1936)

Os embates entre erudito e vanguarda, de um lado, e popular e folclore, de outro, refletem a duvidosa oposição entre o universal e o particular no problema da politização e da nacionalização da arte na primeira metade do XX, e precisam ser contextualizados historicamente, considerando o lugar em que se situam em relação ao mundo capitalista em plena expansão, com o consequente crescimento da exploração, seja de mão de obra, seja de outras nações. No Brasil, a articulação de um discurso de nacionalização musical, interessado pelo folclore e pelo popular para a construção de uma identidade, ocorre no momento de maior exaltação nacionalista e imperialista na Europa, ao mesmo tempo em que a ascensão dos Estados Unidos acena para um novo modelo de imperialismo e de intervenção externa, especialmente nas nações latino-americanas. Internamente, a ascensão da burguesia promovida, sobretudo, pelo acentuado processo de industrialização e inserção do Brasil no capital internacional contribui para a potencialização dos conflitos internos.

O referido processo, acompanhado por uma complexificação e fragmentação da sociedade, acentua as distinções constitutivas da sociedade e, por conseguinte, a ininteligibilidade de sua estrutura, dificultando a fixação das distinções em uma articulação devido ao excesso de sentido do social, como estipulam Ernesto Laclau e Chantal Mouffe (1987, p.110). Laclau e Mouffe (1987, p.212-213) entendem que um dos perigos para a democracia consiste no totalitarismo e sua negação da divisão social, uma vez que o poder pretende se materializar como representante do povo uno e, assim, negar a pluralidade em nome da unidade. O outro perigo consiste no oposto, ou seja, na falta de referencial para uma unidade que, apesar de sua impossibilidade, representa um horizonte para impedir a implosão do social diante da falta de articulação entre as relações sociais, o que constitui uma forma de desaparição da politicidade. Sob o pano de fundo da crise da democracia, intensificada pelas desigualdades sociais preservadas nas formas de subordinação e de opressão, o interesse pelo folclore e pelo popular por parte do nacionalismo musical ambiciona elaborar simbolicamente um referencial comum que recupere a politicidade do social.

A construção deliberada de uma tradição musical brasileira a partir da imediaticidade funcional e da atitude receptiva interessada, desprovida dos preconceitos da prematura psicologia das massas, deve, portanto, ser compreendida a partir do conceito de hegemonia e em um contexto de crise das democracias, como uma luta cultural em que a arte, sobretudo a musical, emerge como uma forma de dinamizar o sentimento de pertencimento a uma comunidade nacional e popular, como queria Antonio 
Gramsci (1998), para quem as manifestações musicais são uma expressão da democracia. Como constata Laclau (2011), as identidades populares, como efeito da hegemonia, resultam do conflito entre particularidade e universalidade. Conflito constitutivo, como sabemos, do modernismo, sobretudo na periferia do mundo ocidental. Ali, a exemplo do Brasil, tal conflito representa um problema mais profundo do que o que o embate entre tradição e modernidade poderia traduzir, e em que o nacionalismo assume um significado singular.

O duvidoso conflito entre o universal e o particular esteve no centro do debate do nacionalismo musical no Brasil, tanto como representação universal das demandas populares sob o signo do nacional, sentido do conflito constatado por Laclau, quanto como constituição de uma identidade nacional em oposição ao capitalismo internacional. Contrariamente ao nacionalismo musical que se identifica com a luta de classes e, portanto, com a luta cultural, apelando a aspectos significativos e afetivos das tradições populares, H. J. Koellreutter aposta no universalismo como "construção de um mundo sem fronteiras" (GANDELMAN, 1983, p. 12), o que "requer uma descoberta contínua da própria identidade, redescoberta que liberta de preconceitos nacionalistas, de opiniões infundadas e da reflexão parcial" (KOELLREUTTER, s.d. apud GANDELMAN, 1983, p. 12).

Uma cultura universal, longe, pois, de representar uma perda de identidade que tanto atemoriza os homens de todas as latitudes - demanda uma tomada de consciência das próprias peculiaridades, "o distinto", pois, "como caso particular de algo mais geral" (Heisenberg), ou seja, o distinto como condição de universalidade. (GANDELMAN, 1983, p.12).

Notadamente, os conflitos culturais a partir dos quais os sociais são interpretados e vice-versa representam conflitos na ordem de toda uma tradição da formação humana, problematizada de diferentes formas por intelectuais preocupados com a tarefa da arte na sociedade. Os referidos conflitos e o modo como os intelectuais os interpretam podem ser compreendidos por meio de um contraponto entre, por exemplo, as posições de Antonio Gramsci e as de T. W. Adorno, na Europa, em que pesam os embates entre erudito e vanguarda, de um lado, e popular e folclore, de outro. Contraponto traduzido, de certa forma, no Brasil no conflito que se estabelece entre o pensamento de Mário de Andrade e o de H. J. Koellreutter, promotor do atonalismo e do dodecafonismo de Schoenberg no Brasil.

\section{T. W. Adorno e Antonio Gramsci}

Como suspeita de uma percepção musical que supostamente dispensa a racionalidade, Adorno (2011, p.65) despreza as "excitações instintivas", as quais se convertem, para o autor, em irracionalidade. Muito resumidamente, para Adorno (2011, p.79), irracionalidade, sensualidade e sentimentalidade conformam esteticamente o nacionalismo musical, associado a uma atitude passiva caracterizada pela distração e desconcentração, que indicam psicologicamente uma "fraqueza do Eu". 
Segundo Adorno, os momentos nacionais repercutidos nas composições musicais constituem restos da concepção de nacionalidade que possibilita a imposição do preceito de igualdade dos sujeitos, afinada com a sociedade conformada com a consolidação da burguesia a que subjaz a noção de universalidade que, contraditoriamente, o conceito de nação contradiz. Adorno, para quem a nacionalização se coaduna com a consolidação da burguesia, entende que o uso musical dos caracteres nacionais demarca o momento em que os compositores se convertem politicamente e ideologicamente em representantes das nações. Assim, as escolas nacionais adotam os antagonismos dos diferentes estados nacionais do XIX, com implicações qualitativas, segundo Adorno, que, ao reconhecer que o folclore contempla a conscientização musical coletiva na vida musical de uma nação, conclui que o imediatismo inerente ao primitivismo se converte em falsidade.

Assim, as manifestações musicais tradicionais constituem a origem das formas padronizadas, para Adorno. E, enquanto sintoma da reificação musical, a padronização exige pouco da percepção, de modo que o seu efeito ou função social se delimita aos esquemas de identificação, por meio da qual o ouvinte integra uma comunidade, conforme um "ritual de socialização" (ADORNO, 2011, p.95). Enquanto o nacionalismo musical busca justamente consagrar um ritual de socialização, uma identificação que constitui o resultado da articulação entre uma dimensão significativa e uma dimensão afetiva, sentimental, por meio da tradição musical popular, Adorno considera a socialização uma manifestação vulgar, uma reação condicionada. Para ele, ela representa o resultado da crescente estultificação por meio da qual a passividade se transfere ao pensamento e ao comportamento social, principalmente na forma da pseudoindividualização.

Em contraposição, e contra a separação entre os intelectuais e a atividade intelectual, de um lado, e o povo e a nação, de outro, promovida pelo individualismo e pelo distanciamento elitista dos intelectuais, Gramsci (1998) identifica no folclore um dos elementos para organizar democraticamente a cultura a partir de uma perspectiva nacional e popular, sobretudo diante da necessidade de se consolidar nacionalmente, considerando a situação das nações na periferia do capitalismo. Nesse contexto, a cultura se oferece como totalidade patrimonial do povo ou da nação, de modo que expressa o sentido da unidade intelectual e moral para a conquista das finalidades nacionais e populares. Segundo Gramsci, os fins da luta cultural convergem para a superação de determinadas atitudes diante da vida e do mundo, fundamental para a transformação da sociedade. Assim, compreende o folclore como "concepção do mundo e da vida" de determinados estratos da sociedade em contraposição com as concepções do mundo "oficiais", cultas da sociedade, que compõem a moral dos estratos dirigentes. Para Gramsci, o folclore deve ser estudado seriamente, sendo determinante para o nascimento de uma nova cultura nas grandes massas populares, em que desapareceria a distinção entre cultura moderna e cultura popular ou folclore.

Gramsci (1998) situa a possibilidade de sociabilidade, compreendida como resultado de uma luta cultural, justamente na identificação permitida pelo folclore e pelos cantos populares. O importante, para Gramsci, consiste em estabelecer uma união com 
o povo ou com a nação, uma unidade que, em vez de passiva, seja ativa e viva, e que, ao superar a separação com o povo, corresponda ao problema da elaboração dos sentimentos populares. Ao problematizar a construção da identidade nacional, diferenciando a dimensão nacional, relacionada com a sociedade como um todo, da dimensão popular, relacionada, por sua vez, a um grupo restrito, Renato Ortiz (1986, p.137) observa que,

Ao considerar a cultura popular como heterogênea, na verdade Gramsci a está apreendendo enquanto fenômeno particularizado. A realidade do mundo social é múltipla, daí ela se opor à filosofia, sistema de conhecimento que ordena e compreende esta multiplicidade. $O$ folclore, como universo simbólico de conhecimento, se aproxima do mito e se revela como o saber do particular. A pluralidade da memória coletiva deriva justamente do fato de ela se encarnar no grupo que a representa. Sua fragmentação não decorre de uma pretensa debilidade imanente ao popular, mas sim da diversidade dos grupos sociais que são portadores de memórias diferenciadas. [...] O discurso nacional pressupõe necessariamente valores populares e nacionais concretos, mas para integrá-los em uma totalidade mais ampla. [...] É através de uma relação política que se constitui assim a identidade; como construção de segunda ordem ela se estrutura no jogo da interação entre o nacional e o popular, tendo como suporte real a sociedade global como um todo. (ORTIZ, 1986, p.138-139).

Assim, as identidades, produzidas pela articulação das manifestações culturais a uma totalidade que as transcende, mais do que "expressões da cultura nacional", são "fundamento para uma ação política" (ORTIZ, 1986, p.140-141).

Nesse sentido, reiterando a lição de Gramsci quanto a uma unificação da cultura nacional, Ernesto de Martino (2008) concebe o que denomina "folclore progressista" como uma proposta consciente do povo contra a sua condição socialmente subalterna, que expressa, em termos culturais, as lutas por emancipação. De Martino reafirma a necessidade de unificação, que implica, segundo o intelectual italiano, a incorporação ao circuito cultural das produções populares progressistas que, rompendo com as formas tradicionais do folclore, se vinculam ao processo de emancipação do mesmo povo. De Martino conclui que o folclore progressista representa um modo eficaz de educação cultural, pois constitui, em lugares em que predomina o analfabetismo ou o semianalfabetismo, um progresso cultural efetivo das massas populares, o nascimento real de uma cultura orientada progressistamente. Ao afirmar que não foram apenas artistas de vanguarda que testemunharam os riscos da guerra que cercavam o mundo, relata que os camponeses de um povoado italiano se deixaram ouvir, e o fizeram com uma canção acompanhada pelos instrumentos camponeses, segundo a melodia tradicional.

Adorno (1989), por sua vez, subestima, em sua filosofia e sociologia musicais, a obra de arte tradicional por considerar que ela se priva do conhecimento, devido à sua natureza intuitiva, valorizando a autonomia da vanguarda musical que, segundo o autor, garante sua verdade social. Conforme Adorno, a vanguarda musical promove o conhecimento ao conservar o contraste entre sujeito e objeto. A capacidade de apresentar as contradições sociais que Adorno atribui a uma determinada postura musical, a vanguarda, em detrimento de outra, a alienada, apresenta, no entanto, as suas contradições, como observa Alvaro Valls (2002), a exemplo de sua postura associada ao problema da 
reificação do processo receptivo, cuja solução se encontraria na supressão da alienação por uma elite contra a "simples massa" (VALLS, 2002, p.118).

Para Adorno, embasado na concepção kantiana de arte como finalidade sem fim formulada no processo de emancipação da burguesia, a autonomia da arte musical se coaduna com o afastamento dos ouvintes. Assim, Adorno associa leviana e rapidamente o folclorismo, especialmente sua suposta aversão pela autonomia subjetiva, com a ideologia do totalitarismo, que se organiza "no folclorismo para a austeridade sangrenta e fascista de uma mentalidade musical que menospreza a universalidade" (ADORNO, 2011, p.315). Adorno (2011, p.318) conclui, disso, que o poder de integração que no classicismo vienense exprimia a humanidade se converte em "um modelo de Estado integral".

Se o contexto internacional de crise promove os imperativos sociais que justificam a necessidade de responsabilidade da arte, a responsabilidade se configura de maneiras visivelmente diferentes. Entre, por exemplo, o pensamento gramsciano e o adorniano, fundamentado na concepção de um sujeito racional dotado de autonomia, a responsabilidade da arte se oferece de forma praticamente oposta, tanto pelo problema da sensibilidade quanto do distanciamento. Contudo, o folclorismo que coincide com a consolidação tardia da burguesia nas periferias do mundo ocidental não se trata simplesmente de uma atribuição de identidade, mas, como se pode inferir da proposta de nacionalização de Mário de Andrade, de interferir politicamente no processo de construção da nação e de seus valores, contrariando os valores da burguesia. Como constata Florestan Fernandes (1994, p.147), com o aproveitamento do folclore, a arte erudita se coloca "a serviço das objetivações das camadas populares, matriz e celeiro do folclore, podendo captar da mesma forma que este o significado e o sentido da vida coletiva", conclui o autor, frisando que "servir" significa incorporar e desenvolver por meio de processos dinamicamente renovados pelo viver em comum.

De todo modo, com suas suspeitas em relação ao nacionalismo musical, compreendido como transfiguração da participação da arte musical na emancipação da burguesia, Adorno (2011) afirma que o nacionalismo acusaria a vanguarda musical de desagregadora e intelectual, incluindo os folcloristas de nações subdesenvolvidas cuja economia se fundamenta principalmente na agricultura. E, com efeito, o nacionalismo musical no Brasil acusaria a vanguarda de desagregadora e intelectual, fazendo do compositor H. J. Koellreutter, que aporta no Brasil em 1937, o seu alvo principal.

\section{H. J. Koellreutter e o nacionalismo musical brasileiro}

Com a instauração do Estado Novo, caracterizado pelo centralismo, pelo nacionalismo e pelo autoritarismo, e com a polarização do Partido Comunista, as fronteiras entre arte e sociedade se estreitam definitivamente, potencializando a oposição entre o nacionalismo e o suposto universalismo. A transfiguração da participação da música na emancipação da burguesia que Adorno identifica no nacionalismo musical, no entanto, seria compreendida aqui, conforme os preceitos do realismo socialista, sob o signo do otimismo do tonalismo em contraposição ao pessimismo inerente ao decadentismo das vanguardas musicais. 
Ainda em 1941, aproximadamente dez anos antes da publicação da Carta Aberta que contribuiria para a dissolução do grupo Música Viva, fundado por Koellreutter, e para a sua rejeição, o atonalismo sugeria a Camargo Guarnieri (1941 apud KATER, 2001, p.282), autor da Carta, "um problema, o do belo". Para Guarnieri, o problema do belo no atonalismo deriva de sua demasiada intelectualidade, em detrimento de emoção e comoção, segundo o compositor, que admite, no entanto, o "interesse" suscitado pela composição de Koellreutter. A suspeita de formalismo, hermetismo, sectarismo, elitismo, proveniente da referida perspectiva, que se aplica ao atonalismo e, por conseguinte, a Koellreutter, perseguiria o compositor desde que aportou no Brasil. O problema reapareceria na Carta Aberta publicada em 1950, em que Camargo Guarnieri acusa o atonalismo e o dodecafonismo, por seu formalismo, de degenerar o aspecto nacional da arte musical brasileira. Guarnieri afirma a necessidade de "deter a nefasta infiltração formalista e antibrasileira", priorizando o folclore, compreendido como expressão viva da nacionalidade.

Ao responder publicamente aos argumentos de Guarnieri, Koellreutter define o dodecafonismo tecnicamente como um meio para a estruturação do atonalismo, que concebe como uma linguagem musical em formação e, logicamente, como resultado de uma evolução e da conversão de mutações quantitativas do cromatismo em qualitativas. O compositor argumenta que o dodecafonismo "não é mais nem menos 'formalista', 'cerebralista', 'antinacional' ou 'antipopular'" que o contraponto e a harmonia tradicionais:

É errôneo, portanto, o conceito de que o dodecafonismo "atribua valor preponderante à forma" ou "despoje a música de seus elementos essenciais de comunicabilidade"; que "Ihe arranque o conteúdo emocional"; que "Ihe desfigure o caráter nacional" e que possa "levar à degenerescência do sentimento nacional". (KOELLREUTTER, 1951 apud KATER, 2001, p.128-129).

Ao afirmar que o dodecafonismo "garante liberdade absoluta de expressão e a realização completa da personalidade do compositor", Koellreutter conclui, em contraposição a Guarnieri, que a degeneração do "sentimento nacional" deriva, antes, do nacionalismo em sua forma de adaptação de expressões vernaculares:

Essa tendência, tão comum entre nós, é responsável por uma música que lembra o estado premental de "sensação", próprio do homem primitivo e à criança, e que, com as suas fórmulas gratuitas emprestadas ao colorismo russo-francês, não consegue encobrir sua pobreza estrutural e a ausência de potência criadora. O verdadeiro nacionalismo é um característico intrínseco do artista e de sua obra. (KOELLREUTTER, 1951 apud KATER, 2001, p.129).

O compositor critica a "situação de estagnação mental em que vive amodorrado o meio musical brasileiro", constatando, no entanto, que os "jovens dodecafonistas brasileiros" "jamais desprezaram o folclore de sua terra", uma vez que o assimilaram essencialmente ao compor a partir da materialidade musical. Assim, o seu realismo, em que se fundamenta o valor humano do trabalho dos jovens compositores, deriva, apesar da perfeição estrutural do dodecafonismo, da instabilidade e fragmentação provenientes 
de uma crise que resulta do conflito entre a forma e o conteúdo da arte, "a fonte mais importante do desenvolvimento e do progresso das artes". O compositor critica, por fim, "o nacionalismo exaltado e exasperado" que condena a contribuição de um grupo de jovens compositores para a cultura musical do Brasil e que

[...] conduz apenas ao exacerbamento das paixões que originam forças disruptivas e separam os homens. A luta contra essas forças que representam o atraso e a reação, a luta sincera e honesta em prol do progresso e do humano na arte é a única atitude digna de um artista. (KOELLREUTTER, 1951 apud KATER, 2001, p.130).

Com a perseguição ao atonalismo e, por conseguinte, à sua pessoa, Koellreutter contestaria constantemente as publicações a seu respeito. No artigo "Contestando afirmações infundadas", por exemplo, contesta as afirmações de Eurico Nogueira França a respeito da incapacidade de instrumentista e de professor de composição, que, inclusive, prejudicaria os alunos, e que teria sido preso em São Paulo como suspeito de exercer atividades nazistas. "Afirmações que distorcem a realidade dos fatos e tentam prejudicar minhas atividades profissionais", contesta Koellreutter (1946a, p.53), argumentando: "É sobejamente conhecida minha completa e espontânea dedicação às coisas do Brasil e o meu trabalho, o qual visa unicamente servir ao desenvolvimento da cultura brasileira". Do mesmo modo, Koellreutter (1944a, p.57) contestaria as acusações contra os compositores modernos por parte de Madame D'Or, nome com o qual Ondina Ribeiro Dantas assinava seus artigos:

Discutindo o valor artístico da música hodierna e referindo-se aos compositores contemporâneos Paul Hindemith, Schoenberg e Honnegger, que "desprezaram as regras, os conceitos da verdadeira arte da harmonia clássica e antiga, apenas empregada por eles, evasivamente, num falso acatamento do passado", a ilustre crítica do Diário de Notícias, Madame D'Or, num artigo intitulado "A produção moderna", diz o seguinte: "Dessas inovações nada resulta senão experiências atrevidas: dessas insubordinações nada surgiu, até agora, senão o caos. Já não se sabe o que é música. Afinal, para onde vamos, o que nos espera, se a vitória, se a derrota definitiva".

Notadamente, as afirmações de Ondina Ribeiro Dantas revelam explicitamente o conflito cultural por meio do qual se compreendem os conflitos sociais. Ao tomar partido dos compositores modernos, Koellreutter critica a "forma em si" na música e afirma assistir a uma "madrugada de um novo classicismo" que, em contraposição a uma compreensão da música como pintura, a torna "o objeto principal de suas preocupações", incluindo em seu horizonte os compositores brasileiros Camargo Guarnieri, Claudio Santoro e Guerra-Peixe:

[...] esses compositores parecem participar, todos, da criação de uma nova linguagem sonora e da construção de um novo estilo. $O$ futuro pertence àqueles, dentre os jovens, que, sem concessões, prosseguirem com firmeza a rota que se traçaram e que conseguirem encontrar, com puro pensamento, novas formas, formas perfeitas, as únicas capazes de assegurar, pelo conteúdo que tiverem de emoção humana a perenidade das obras que deixarem, depois que todo sabor de novidade as tiver abandonado. (KOELLREUTTER, 1944a, p.38). 
O futuro se desviaria, no entanto, da rota idealizada por Koellreutter para os jovens compositores brasileiros, com a dissolução do grupo que formou, o Música Viva, e a rejeição publicamente declarada de seus colegas ao compositor e ao atonalismo e dodecafonismo. Nesse sentido, Claudio Santoro antecipa proposições da Carta Aberta de Guarnieri, como o problema do belo, que para o compositor se associa com o potencial de participação social da arte, defendendo o emprego do folclore e do popular (SILVA, 2001).

Mas Santoro reproduz o discurso proveniente de uma interpretação materialista um tanto reducionista da evolução musical, compreendida como reflexo da evolução social. Santoro prioriza o efeito da obra sobre o ouvinte, restrito ao otimismo ou ao suposto pessimismo do decadentismo das vanguardas musicais, as quais refletiriam o "impasse em que se encontra 'toda arte burguesa'" e que, segundo Santoro (1948, p.233-234), representa o decadentismo "em que se acha esta classe ainda dominante". Para Santoro, portanto, a relação da evolução da arte com sua razão, ou seja, a evolução social, seria compreendida sob o signo do realismo socialista, de modo que ecoa o apelo dos compositores reunidos em Praga por uma música que corresponda "aos anseios da sociedade nova, aos anseios da classe laboriosa, e que seja a expressão da verdadeira cultura popular arte para todos", a qual se enraizaria "no povo e nas tradições nacionais" (SANTORO, 1948, p.235).

Assim, critica o formalismo de "toda arte abstrata e desligada da realidade social", desprovida de fundamentação na "cultura popular" e, diante da crise da música moderna, ecoa a proposição de um retorno ao XIX que representaria o momento de ascensão da classe burguesa:

O "Belo" no sentido humanista deverá expressar este novo ideal. Para nós a obra de Schoenberg e algumas de Strawinski carecem de "beleza", por não terem contato com a massa, servindo unicamente um pequeno círculo privilegiado. Formalista é assim toda criação segundo o princípio de "arte pela arte" sem olhar a necessidade de achar uma relação entre esta arte e a sociedade em que vive o criador. (SANTORO, 1948, p.235).

Em detrimento de uma arte para o futuro, da "arte pela arte", que priva de senso e realidade a participação do compositor na "luta ao lado do povo e na defesa da real cultura", Santoro (1948, p.237) preconiza a utilidade "com a sua mensagem, buscando uma relação com o povo". Ao afirmar a necessidade de pisar a terra e acabar com a noção de sujeito individual criada pela sociedade burguesa, em nome da função da obra de arte na "luta pelo progresso e pela humanidade", conclui: "Nada mais desejam os inimigos da cultura e da arte a serviço do povo que o afastamento e o isolamento" (SANTORO, 1948, p.239). Ao identificar as obras atonais com o pessimismo que conduz o ouvinte a estados de contemplação e abatimento moral, menciona Koellreutter:

Este problema que me preocupa depois de 1945 foi objeto de longas discussões com Koellreutter, sem chegarmos a um completo esclarecimento da matéria. Hoje, o esclarecimento está feito, sobre a função que deve ter a obra de arte, e é preciso agora trabalhar nesse sentido, procurando a realidade positiva que deve ter a criação artística. Esta realidade deve ser procurada e fundamentada, por 
cada povo, por cada nacionalidade, para que esta linguagem, além do conteúdo positivo, reflita também o aspecto característico do povo, baseando-se na canção e no ritmo popular. Esta escolha deve ser cuidadosa e não arbitrária como já foi muitas vezes nos nossos compositores folcloristas, porque a manifestação da massa, nem sempre teve um caráter positivo, por exemplo os cantos dos pretos escravos resignados com sua arte e inferioridade tem um caráter negativo e apresenta-se para nós somente como um valor histórico social, para o estudo étnico, mas tem um lado perigoso para aproveitamento n'um sentido construtivo. (SANTORO, 1948, p.238).

Assim, Santoro idealiza, por fim, uma obra para o povo, sob uma nova forma que se diferencie do exotismo proveniente da imitação dos movimentos nacionalistas da Europa. E, apesar de seu afastamento da vanguarda musical, Santoro conclui com uma postura similar a Adorno, ao criticar a "arte estandardizada e comercial" do jazz imposto pelo imperialismo americano, apelando, no entanto, para a cultura popular: "Apelo daqui ao nosso povo, para que reaja na defesa da nossa cultura popular, para que ela não seja despedaçada pelo povo inimigo da humanidade: o fascismo disfarçado, o imperialismo americano" (SANTORO, 1948, p.239).

O compositor Guerra-Peixe, por sua vez, ao romper com as propostas musicais de Koellreutter, e questionar publicamente a compreensão de universal de Koellreutter, compactua com o nacionalismo musical. Assim, defende que o compositor brasileiro deve trilhar "a senda do nacionalismo baseado diretamente nas fontes populares", cujos elementos forneceriam os valores para a criação de uma escola brasileira. Guerra-Peixe (1952, p.3) observa que "o sentido de nacionalidade vem sendo ampliado" em termos de "diferenciações culturais" que diversifiquem as "manifestações espirituais e materiais que a humanidade apresenta". Ao declarar o abandono do dodecafonismo pela impossibilidade de acentuar em suas obras a sua nacionalidade, bem como pela incomunicabilidade de sua linguagem, reconhece a "covardia de que eu era presa, fugindo aos problemas da criação de uma música necessariamente brasileira":

O dodecafonismo se ajusta a essa gracinha de minoria existencialista, que tem por fundamental prazer o sentir-se isolada do mundo, divertindo com os seus exóticos e irresponsáveis requintes intelectuais. E o hermético sistema musical é uma característica do período decadente dessa classe que estertora nos seus mais trágicos momentos. (GUERRA-PEIXE, 1952, p.3).

Ao reproduzir a ideia do decadentismo da classe burguesa que se expressaria nas vanguardas musicais, argumenta que "a história das artes nos aponta os exemplos em que as novas orientações vão sempre de mãos dadas com as classes que passam à posição dominante na sociedade. Logo, música pra agonizante é toada de velório...", conclui Guerra-Peixe (1952, p.3). Preocupado com a socialização da arte, o compositor defende "aquela justa e humana condição de comunicabilidade", apontando para a construção de uma tradição erudita nacional distinta dos padrões europeus e com valor social:

[...] na música dodecafônica chegamos a uma verdadeira tirania imposta pelos limites a que nos conduz a discutida técnica dos doze sons, aparentemente rica de possibilidades. Aliás, o professor H. J. Koellreutter - o introdutor do dodeca- 
fonismo no Brasil - é o primeiro a reconhecer que Schoenberg - a figura máxima do dodecafonismo mundial - é o "continuador intransigente de um caminho que ele próprio denomina a tradição musical germano-austríaca por excelência". (GUERRA-PEIXE, 1952, p.3).

Em seu artigo "Que ismo é esse, Koellreutter?", preocupado com a identificação com o povo por meio do emprego do folclore pelos compositores brasileiros, Guerra-Peixe (1953, p.33) questiona a pretensão de universalismo da música brasileira apregoada por Koellreutter, questionando o universalismo da escola de Viena:

O que é música universal, professor Koellreutter? Quem a compôs ou compõe? Quando? Onde? Como? Em que país? Ou são escolas nacionais que se formam, se divulgam, se impõem e que, como produto de culturas altamente estratificadas, passam a exercer influência sobre a música de outras culturas?

Ao acusar a substituição por Koellreutter do termo "etnicamente" por "tecnicamente" ao supostamente plagiar um texto de Lopes Graça, Guerra-Peixe (1953, p.35) conclui que Koellreutter "tem verdadeira ojeriza por qualquer coisa que possa fazer sentir a nacionalidade brasileira. Pois, para o germânico, o brasileiro nunca será etnicamente aquilo que precisamente o diferencia de qualquer outro":

É curioso como o professor Koellreutter muda algumas palavras na cópia que faz, a fim de encontrar "exageros nacionalistas" num país onde é enorme a indiferença pelos valores culturais nativos. Onde o maior empecilho na formação da escola nacional brasileira reside, justamente, no cosmopolitismo gratuito que penetra a nossa criação musical. É horroroso o estabelecimento de "uma nova concepção na música brasileira", como anunciavam os dodecafonistas encabeçados pelo professor Koellreutter - quando na realidade, doa a quem doer a verdade, ainda nem sequer chegamos a afirmar a nossa nacionalidade na música erudita, embora se progrida nesse sentido. (GUERRA-PEIXE, 1953, p.35).

Guerra-Peixe critica a sua obra e a de seus colegas, Claudio Santoro e Eunice Catunda, a qual, ao abandonar o dodecafonismo, como seus colegas, nega que o dodecafonismo seja uma "linguagem musical". Catunda afirma que o dodecafonismo cria "um academicismo e uma ortodoxia", "produto daquele mundo decadente que produziu Schoenberg" (SILVA, 2001, p.139). Continua Guerra-Peixe:

Ou é, então, evidente a intenção do professor Koellreutter menosprezar as correntes ligadas esteticamente à música popular brasileira, como se elas fossem uma espécie de "concessão" e de "exterioridade" e como se a "influência de folclore" os "característicos de país ou raça" e, ainda, alguma tendência a conservar o tonalismo [...] fossem motivo de rebaixamento artístico ou incoerência estético-ideológica... Entretanto, por outro lado sou forçado a reconhecer que na obra dodecafônica de Santoro - assim como na de Catunda e na minha há característicos de país e raça, sim. Mas, só que de país e raça germânicos... (GUERRA-PEIXE, 1953, p.34).

Guerra-Peixe (1953, p.35) afirma, por fim, que "o leader dodecafonista" esquece que o nacionalismo musical constitui uma fase a todas as nações que pretendem criar 
sua escola musical. E conclui explicitando o abandono do atonalismo e do dodecafonismo pelos jovens compositores brasileiros: "Agora resta-me perguntar a Koellreutter: - É nessa escola assim tão avançada que tem formado os seus últimos alunos, desde que Claudio Santoro, Eunice Catunda e eu abandonamos o formalismo dodecafônico? Que 'ismo' é esse?...".

Nesse sentido, em um artigo intitulado "Koellreutter, charlatão e plagiário", Rossine Camargo Guarnieri, irmão do compositor Camargo Guarnieri, autor da Carta Aberta, questiona a honestidade de Kollreutter, explicitando, para tanto, sua nacionalidade, ao acusar o compositor de fins "escusos e falsos". Rossine Camargo Guarnieri (1952, p.26) usa a prisão de Koellreutter "sob a acusação de exercer atividades em favor do hitlerismo" contra a "figura de 'perseguido antinazista'":

Pessoalmente eu sempre tivera a convicção de que H. J. Koellreutter era um aventureiro, um charlatão que aqui aportara disfarçado em "perseguido político", incumbido de ganhar a confiança dos círculos mais progressistas de nossa cultura, com o objetivo de semear as suas ideias dissolventes sob o disfarce de uma linguagem revolucionária.

Incapaz de associar o atonalismo e o dodecafonismo ao comunismo, o autor conclui que o compositor se revela um "bifronte", na medida em que se associa aos comunistas no Brasil "ao mesmo tempo que tratava de reunir alguns incautos para organizar um movimento de 'renovação artística' a que deu o nome de 'Música Viva'":

H. J. Koellreutter foi consolidando sua posição e disseminando no meio musical brasileiro as suas perniciosas teorias estéticas. Preparando o terreno, o aventureiro introduziu no Brasil o dodecafonismo - escola de fabricação de compositores em série destinada a desfigurar a música brasileira, tornando-a uma expressão da gagueira cacofônica do cosmopolitismo. (GUARNIERI, 1952, p.26)².

O autor termina denunciando a artistas e intelectuais honestos "a respeito de um aventureiro sem escrúpulos - rebotalho do lodaçal onde apodrecem os mumificados representantes de uma cultura decadente - que aqui apareceu com a finalidade de corromper e desnacionalizar a música brasileira". E finaliza: "Confesso que trato deste caso do charlatão e plagiário H. J. Koellreutter com a repugnância de quem escalpela um fedorento tumor" (GUARNIERI, 1952, p.28).

\section{H. J. Koellreutter e Mário de Andrade: o Café}

Não podemos compreender a musicalização por Koellreutter de um poema do principal articulador do nacionalismo musical no Brasil destinado a ser sua obra mais

\footnotetext{
2 Acerca do manifesto, afirma o autor do artigo: "O manifesto de lançamento de 'Música Viva', publicado em 1946, é um amontoado de sandices e contradições as mais estúpidas - expressão VIVA da incurável duplicidade do seu autor". Segundo o autor, "a técnica fundamental de H. J. Koellreutter era envolver nesse movimento os nomes de maior projeção na vida cultural do Brasil. Assim é que Villa-Lobos, Francisco Mignone, Camargo Guarnieri, Mário de Andrade, Brasílio Iteberê, Luiz Heitor etc. viam-se constantemente citados nas publicações dirigidas por Koellreutter e seus comparsas".
} 
"socialista", a ópera coral ${ }^{3}$ Café, a ser musicado por Francisco Mignone, como uma resposta aos conflitos entre erudito e vanguarda, popular e folclore, universal e particular, cosmopolitismo e nacionalismo musical? Afinal, no interior de tais conflitos, e oposto ao nacionalismo musical, Koellreutter simboliza um formalista, um elitista, um promotor do distanciamento social e, no limite, um nazista, como vimos.

Ponto culminante de sua busca por uma interlocução com a obra de Mário de Andrade $^{4}$, a musicalização de Café parece corresponder ao problema da evolução musical frequentemente reiterada pelo compositor. Como se se propusesse a atualizar as ideias musicais de Mário de Andrade segundo o seu ideal de uma "educação da massa" em um "sentido moderno" (KOELLREUTTER, 1945, p.54), exposto em sua releitura de "O Banquete", publicada no mesmo ano da morte do poeta modernista5. Ao musicar o poema com uma linguagem nova, que, ao seu ver, elevaria a coletividade, em oposição ao reacionarismo que identifica no uso da linguagem musical dos séculos XVIII e XIX, Koellreutter parece procurar afinar o tema da obra, a revolução, com a linguagem musical, renovada não apenas pela revisão do discurso do compositor que, a partir meados dos anos 1940, absorve problemas comuns ao nacionalismo musical ${ }^{6}$, mas com novas pesquisas musicais, como a aleatoriedade, que introduziu no Brasil em meados dos anos 1950.

Afinal, como explica nos anos da apresentação da musicalização de Café, Koellreutter (1995, p.11) identifica "na mudança de função dos ciclos sonoros da partitura moderna e na transformação dos mesmos em relação de relacionamentos" implicações na arte musical que representam "uma reviravolta muito maior na sintaxe da linguagem musical do que a causada por dodecafonismo ou serialismo", os quais conservaram intactos, segundo o compositor, os fundamentos da composição musical. Ao postular que a arte constitui a "superestrutura da transformação da sociedade", Koellreutter

Mário de Andrade (2013b, p.52-55) hesita ao definir o Café, utilizando "oratório secular", "teatro cantado" e, finalmente, "ópera coral". Evita, inicialmente, "ópera", porque "ela se tornara numa exclusiva arma de classe dominante. Ópio do povo, gozo de ricos. Na verdade a ópera, já com este nome, é uma coisa odiosa", escreve na introdução, escrita em dezembro de 1942. Mário de Andrade se pergunta, por fim, se "não se poderia acaso tentar uma ópera coletiva", que não se tratasse apenas de "uma ópera que interessasse coletivamente a uma sociedade, mas que tivesse uma forma, uma técnica mesma derivada do conceito de coletividade", chegando, assim, à definição de "ópera coral". "Um melodrama que em vez de indivíduos, lidasse com massas". Koellreutter, por sua vez, define o Café como uma "tragédia secular".

$4 \quad$ Além da constante retomada, direta e indireta, da obra de Mário de Andrade em seus textos e manifestos e da menção ao autor em entrevistas, Koellreutter envia a Mário de Andrade um cartão de visitas como chefe do departamento de publicações musicais do Instituto Interamericano de Musicologia, fundado por F. C. Lange, e uma carta-convite, datada de setembro de 1942, para a estreia de uma sonata de Claudio Santoro, "talvez a obra mais pessoal e mais interessante deste jovem compositor brasileiro" (KOELLREUTTER, 1942). Em entrevista ao Jornal do Brasil, publicada em novembro de 1975, perguntado sobre a situação da música contemporânea, Koellreutter afirma estar trabalhando com Café há vinte anos: "Senti na pele o problema como compositor, querendo musicar a obra O Café, de Mário de Andrade. Comecei a fazê-lo há 20 anos. Escrevi o princípio e o fim, embatuquei no restante [...]. No ano passado, decorrido tanto tempo, vi que já tinha condições de escrevê-la e em seis meses a terminei. O problema foi encontrar uma linguagem musical que complementasse o texto [...]. Passei 20 anos mergulhado no Café" (BARBARA, 1975, p.5). No arquivo de Koellreutter se encontra ainda um projeto de musicalização de Macunaíma, de Mário de Andrade. A esse respeito, ver Breunig (2016).

$5 \quad$ Cf. Koellreutter $(1945,1948)$.

$6 \quad$ O "Manifesto 1946", publicado pelo grupo Música Viva em novembro de 1946, declara, por exemplo, "a música como produto da vida social", "expressão de uma cultura e de uma época" e "a concepção utilitária da arte", assumindo uma "postura revolucionária essencial". "Uma última observação sobre o 'Manifesto 1946'", escreve Neves (1981, p.96), "se refere à frequência e à força com que é abordado o problema da 'funcionalidade' da obra de arte (o que faz imediatamente pensar todos os escritos de Mário de Andrade, que, falecido dois anos antes, não chegou a ver a conversão dos dodecafonistas à sua causa social) e da necessidade de engajamento concreto dos compositores". 
(1995, p.25) emprega uma linguagem marxista para reafirmar o papel da arte na transformação da sociedade. A integração do conteúdo da obra com a linguagem musical se revela na medida em que o "tema da revolução popular" que, para Koellreutter, apresenta o aspecto de um mito, ou seja, a superação de uma oposição dual, o induz, como revela o compositor em entrevista ao caderno Mais!, ao emprego combinado de procedimentos composicionais da "nova arte" musical, como a planimetria, o serialismo, a aleatoriedade, o atonalismo e o dodecafonismo (ADRIANO; VOROBOW, 1999).

Ao mesmo tempo, e não obstante, a musicalização de Koellreutter se contrapõe ao realismo socialista advogado pelos compositores nacionalistas, especialmente depois do Congresso Internacional de Compositores, que influenciaria, inclusive, a nova geração de compositores brasileiros. O realismo constitui um dos problemas fundamentais das contraposições de Koellreutter ao nacionalismo7, ao qual Koellreutter parece propor um realismo que, podemos inferir, decalca da obra de Mário de Andrade. Afinal, o "realismo primitivista" de Mário de Andrade se opõe, como nota Raúl Antelo (1986, p.100), ao modelo da contemplação "desinteressada do civilizado, que aceita o real como dado", propondo uma arte anticartesiana e funcional. Mas o primitivismo de Mário de Andrade rememora a cultura coletiva popular, sugerindo, por meio do contato com o popular, a passagem do sentir ao conhecer para voltar ao sentir, o que potencializa, como conclui Antelo, a apreensão da realidade e a sua transformação. $O$ seu realismo se contrapõe, assim, aos efeitos globalizadores da racionalidade moderna, reproduzida pelas classes dirigentes, tanto que, durante o Estado Novo, foram proibidas muitas manifestações culturais de origem não europeia, as quais serviriam como substrato para a nacionalização musical.

Por sua vez, Koellreutter acreditava, como demonstra em artigo de 1944, na substituição dos estilos nacionais por um continental, de modo que a arte musical, conforme sua projeção de uma futura humanidade, seria reconhecida simplesmente como americana ou europeia. Com a transformação social em curso, os problemas do homem suplantariam a nacionalidade, constituindo uma arte mediadora dos povos, que contribuiria para a salvação da liberdade intelectual:

A linguagem sonora, idioma universal, parece-me a arte predestinada a cumprir esta tarefa. E já se movimentam forças entre os jovens compositores deste continente, em cujas obras, - de atitude francamente americanista - as ideias pessoais, imaginação criadora, conhecimento, da evolução musical e ética espiritual substituem a imitação servil e o disfarce à maneira europeia de temas indo-americanos ou afro-americanos de medíocres produções de música "folklórica". (KOELLREUTTER, 1944c, p.47).

\footnotetext{
$7 \quad 0$ realismo na arte musical seria o ponto fundamental do desacordo entre Koellreutter e Claudio Santoro, sobretudo depois do Congresso Internacional de Compositores, realizado em Praga, em 1948, como o comprovam as suas cartas: "Em que consiste, segundo sua opinião, 0 'realismo socialista' em música? Precisamos primeiro definir bem os conceitos a fim de que possamos discutir. 0 que é 'real', o que é 'irreal' na arte musical?", questiona Koellreutter, interrogando os preceitos do realismo socialista contra a vanguarda musical: "Seja franco, Claudio, e diga-me: não acha que Shostakovitch, Prokofieff, Khatchaturian são tão 'burgueses' em sua música como Hindemith, por exemplo? Eles não se distinguem daquela música que representou o pensamento 'burguês'. Onde está a música que possa representar a sociedade nova, realmente e inteiramente nova, sem preconceitos e verdadeiramente livre? Essa música não existe. Não existe ainda. Mas haverá de existir saindo da luta e do trabalho como a própria organização social. Sinfonia, Sonata, Desenvolvimento, Variação e Cadência, certamente, não poderão ser os característicos da música da nova sociedade" (Cf. KATER, 2001, p.278-279).
} 
Nesse sentido, ainda que afirme que a evolução da expressão musical no Brasil depende da canção popular, e confirme a riqueza do folclore musical e a constante preocupação com o problema nacional por parte dos compositores (KOELLREUTTER, 1946b, p.38), Koellreutter suspeita do folclore, subordinando a emancipação nacional a uma integração entre tradição e progresso e restringindo o folclore aos estudos da musicologia: "[...] o folclore brasileiro constitui ainda, um vasto campo de pesquisa e exploração - não para os compositores em busca de inspiração - mas sim para a verdadeira musicologia" (KOELLREUTTER, 1946c, p.59).

Ademais, Koellreutter revela um acento racionalista e cientificista, caracterizado por uma suspeita dos efeitos e dos sentimentos. Nesse sentido, o que denomina espiritualização do atonalismo corresponde a um proceso de intelectualização que, no entanto e contraditoriamente, evidencia a presunção de transmitir a verdade, tal como em Adorno:

Assim, a música nova, naturalmente, não consegue cumprir a função que uma sociedade saturada esperava da arte: iludir a verdade. Esta arte nova não é meio de gozo - pois, a verdade nunca transmite gozo! - mas sim um meio de edificação transmitindo a verdade e não fugindo do sentido trágico da vida. (KOELLREUTTER, 1944b, p.47).

Ora, o racionalismo e o cientificismo caracterizam, em linhas gerais, a perspectiva eurocentrada, distanciada, que acompanha a epistemologia do colonialismo e do imperialismo, contra a qual o nacionalismo anticolonial se ergue. Basta retomar os termos com os quais Koellreutter contraria os argumentos de Camargo Guarnieri e o nacionalismo musical para perceber tal inclinação: "estado premental de 'sensação'" do "homem primitivo", "estagnação mental", "exacerbamento das paixões", entre outros, que "representam o atraso e a reação".

Posteriormente, durante os anos 1990, quando da apresentação da musicalização de Café, Koellreutter não mais coloca em pauta o folclore e os dilemas da nacionalização musical. No entanto, permanece o acento cientificista amalgamado, agora, com um certo esoterismo e orientalismo, do que parece resultar que a verdade não pode ser acessada pelo homem, e que tudo parece se encaminhar para uma concepção una do universo ou, ao menos, sem dualidades nem contrariedades ${ }^{8}$. Uma compreensão renovada de universalismo aparentemente se delineia, assim, no pensamento do compositor, que reconhece uma propensão oriental para a intuição.

Fundamentadas em um cientificismo a que a arte deveria corresponder, as concepções musicais de Koellreutter constituem a busca de uma representação da nova "imagem do mundo", transformada no XX, como recorrentemente argumenta o compositor ${ }^{9}$. Para Koellreutter, o evento mais importante do XX foi a conscientização do tempo, que gradualmente se torna uma forma de percepção. Com isso, os conceitos 
musicais dualmente opostos, como a dualidade dos modos maior e menor, dos tempos forte e fraco, do primeiro e segundo temas etc., se tornam ultrapassados, comprometendo, inclusive, a presunção de verdade que o compositor atribui ao atonalismo nos anos 1940:

Os conceitos tradicionais, chamados dualistas, as contrariedades, [...] perderam seus significados. Tivemos que aprender que aquilo que chamamos de nossa realidade - com $r$ minúsculo - não é de fato nossa realidade. Tivemos que aprender que a nossa verdadeira realidade - com $\mathrm{R}$ maiúsculo - é um universo dinâmico e inseparável, em que o homem desempenha um papel importante e determinante, influenciando continuamente as propriedades desse mesmo universo e tornando-se cada vez mais consciente de que a verdade é inacessível ao homem. (KOELLREUTTER, 1995, p.7).

Na medida em que compreende que a função do artista deve ser a de contribuir para a conscientização das grandes ideias que formam a nossa realidade atual, os procedimentos composicionais e de escrita de Koellreutter buscam superar o dualismo. Um exemplo seria a planimetria, que, no lugar do pentagrama, organiza serial e estruturalmente os signos musicais em diagramas multidirecionais dispostos no plano. Assim, aleatoriamente, os eventos musicais abandonam a ordem causal e as dualidades dialeticamente opostas, conformando uma nova apreensão do tempo em um "todo ilimitado que leva o ouvinte a perder o senso da forma" (KOELLREUTTER, 1995, p.9-10).

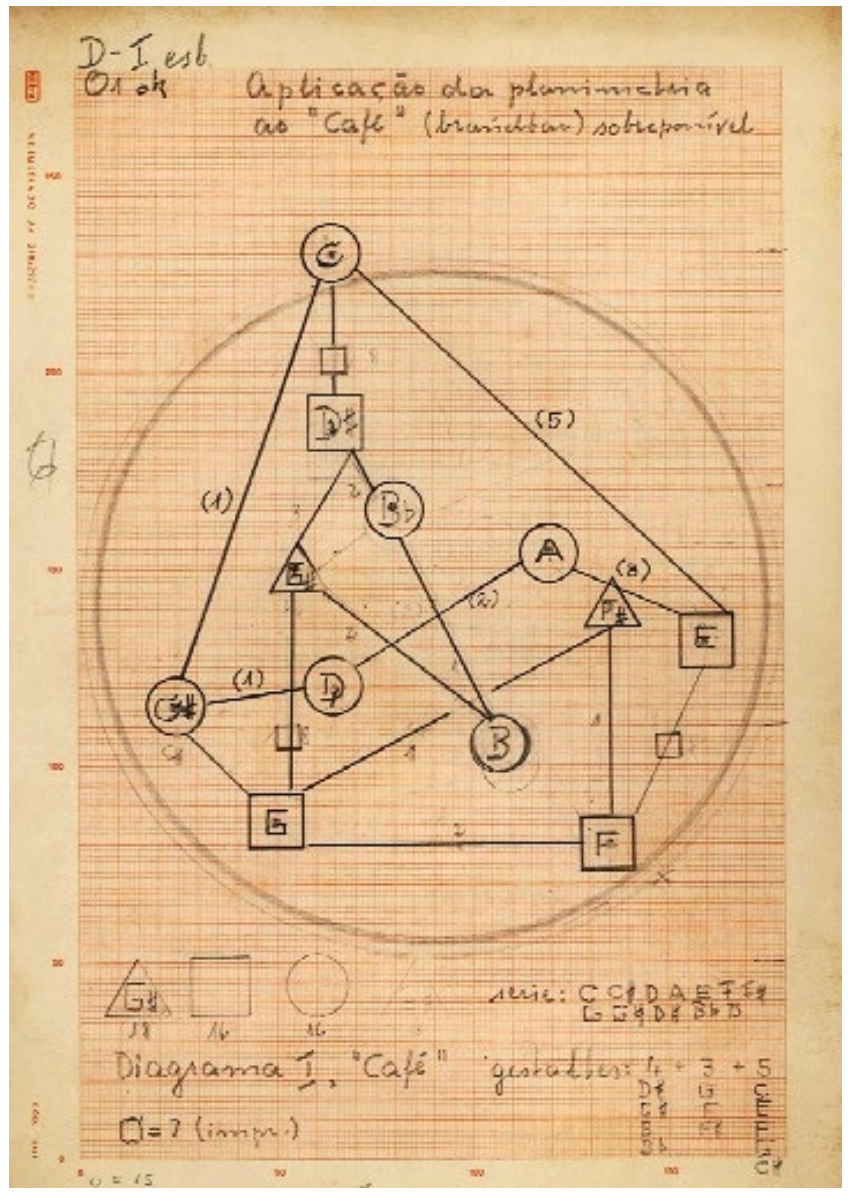

Fig. 1: Planimetria: Diagrama 1 (Cafê). Fonte: Arquivo Permanente da Fundação Koellreutter, UFSJ. Ref. BR MGFK AK.KCO 065 Café. 
Consequentemente, a quadratura, processo de organização da melodia em frases musicais, desaparece no sistema de notação musical de Koellreutter, caracterizado pela indefinição de tempo, de compasso, enfim, pela impossibilidade de quantificar binariamente as composições.

Nesse sentido, a composição para orquestra, coros e solistas para o Café, de Mário de Andrade, consiste, segundo o compositor, em uma linguagem parcialmente modal, tonal e nova. Koellreutter acrescenta ainda um narrador que reproduz fragmentos da "Concepção melodramática", escrita por Mário de Andrade. Em linhas gerais, a composição se caracteriza pela estaticidade, que, conforme as partituras medievais e renascentistas, enfatiza, por meio da monotonia, a linguagem do texto e o contraste em que o compositor insere os elementos de informação ${ }^{10}$.

O coro unissonante dos estivadores do "Coral do queixume", por exemplo, ilustra a monotonia, a estaticidade da altura das notas da melodia, que soa como um canto gregoriano soturno intercalado com o solista.

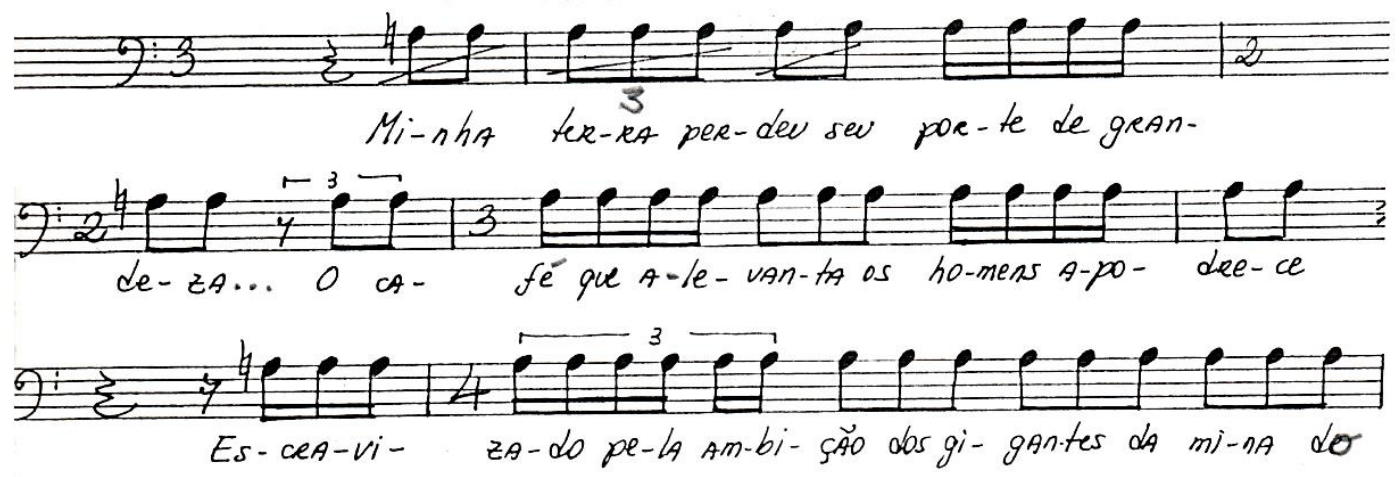

Fig. 2: "Coral do queixume". Fonte: Arquivo Permanente da Fundação Koellreutter, UFSJ. Ref. BrSjFK-HJK 031 Café.

Como exemplo de contraste, a melodia atonal do "jogador solista" do "Madrigal do truco" apresenta grande quantidade de saltos e intervalos dissonantes.

10 Koellreutter define informação como a "qualidade que surge do grau de imprevisibilidade de signos e ocorrências musicais. É responsável pela originalidade da obra musical. Corresponde aos conceitos de surpresa, novidade e improbabilidade" (KOELLREUTTER, 1990, p.77). Koellreutter deixou, junto com as partituras, anotações sobre as regras do contraponto. As mesmas regras comporiam um livro publicado por Koellreutter no mesmo ano da estreia (KOELLREUTTER, 1996). 

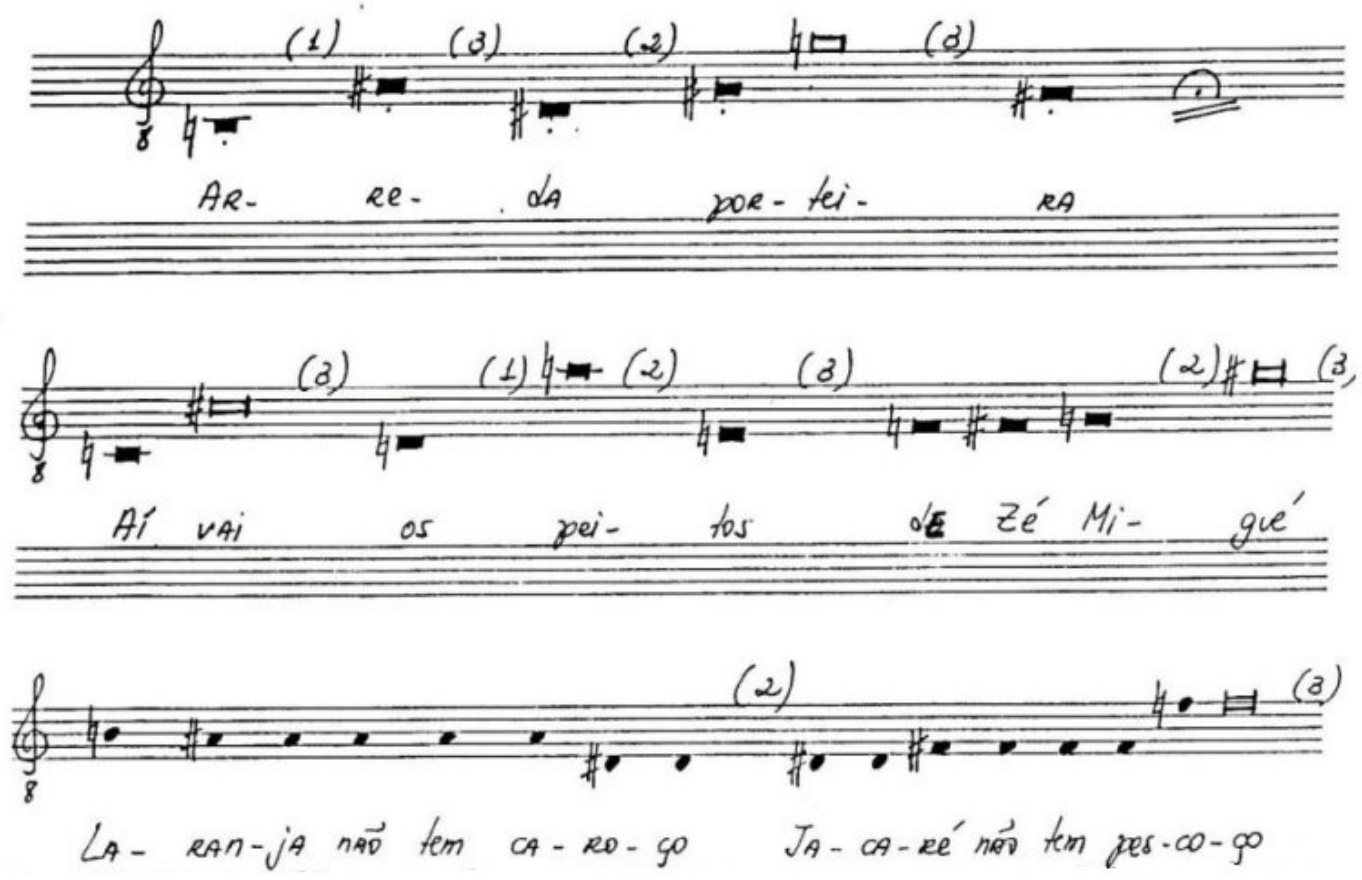

Fig. 3: "Madrigal do truco". Fonte: Arquivo Permanente da Fundação Koellreutter, UFSJ. Ref. BrSjFK-HJK 031 Café.

As figuras empregadas na transcrição da melodia do solista do "Madrigal do truco" não correspondem a um tempo metrificado e definido, mas a uma duração aproximada e com liberdade de interpretação, como Koellreutter explica na partitura. O canto solista, diferentemente do canto coral, goza, evidentemente, de maior liberdade em relação ao tempo, desde que se mensura a composição musical. Mas em Koellreutter, sem unidade e sem barra de compasso, a escrita musical se caracteriza pela irregularidade de ritmo em contraposição ao conceito tradicional de tempo musical e de tempo propriamente dito. Relacionado com a intuitividade, seu conceito de tempo se define pela ametricidade da pulsação natural e pela acronicidade que, ao transcender o tempo medido, rememora, segundo o compositor, um tempo arcaico que precede o conceito e a conscientização do tempo (PIMENTA, 2010, p.630) ${ }^{11}$.

Por outro lado, o compositor emprega ritmos comumente encontrados no folclore e no popular, como no "Grupo madrigalista" do "Madrigal do truco", acompanhado por ritmo de samba executado por pandeiro, tamborim e rebolo:

11 Koellreutter define acrônico como "relativo a um conceito de tempo de categoria qualitativa que se realiza fora do tempo racionalmente medido (de categoria quantitativa)". E amétrico como "disposição dos elementos temporais da partitura que causa a sensação da ausência de pulsação e metro" (KOELLREUTTER, 1990, p.12) 


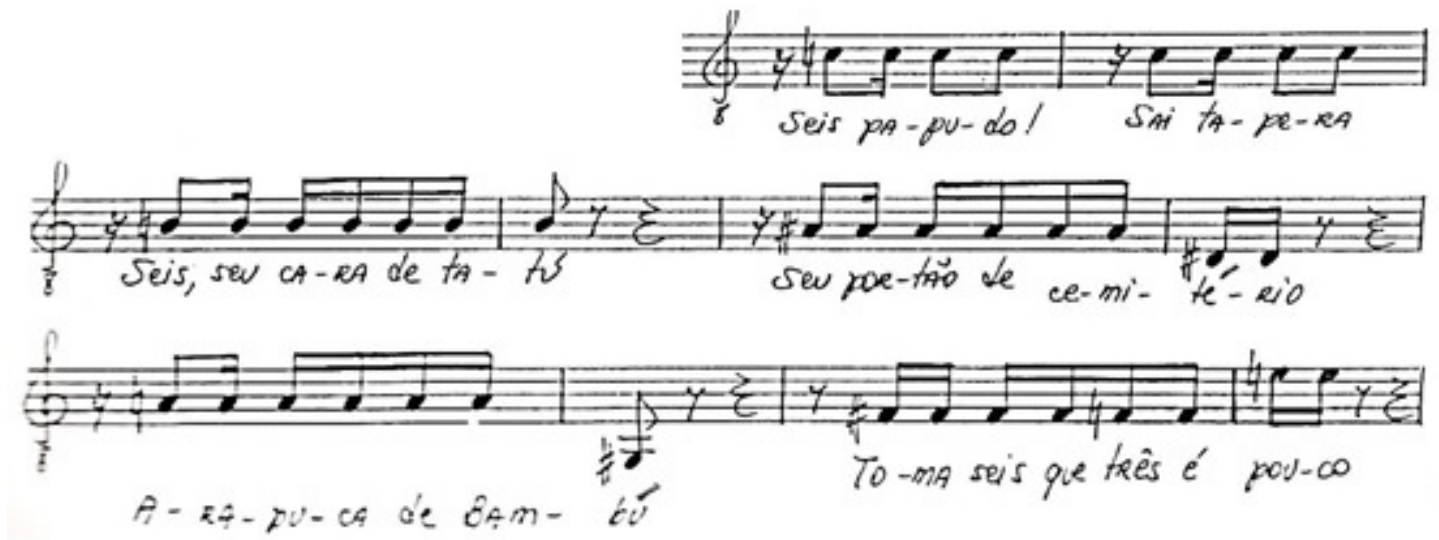

Fig. 4: "Madrigal do truco". Fonte: Arquivo Permanente da Fundação Koellreutter, UFSJ. Ref. BrSjFK-HJK 031 Café.

No "Madrigal do truco", Koellreutter utiliza inclusive a figura que representa a sincopação mais recorrente nas pesquisas musicais de Mário de Andrade, a colcheia entre semicolcheias, a que o pesquisador atribui valor de legitimidade nacional, e a repetição de semicolcheias, sugerida pelo autor do poema para a composição de Francisco Mignone para "A embolada da ferrugem":

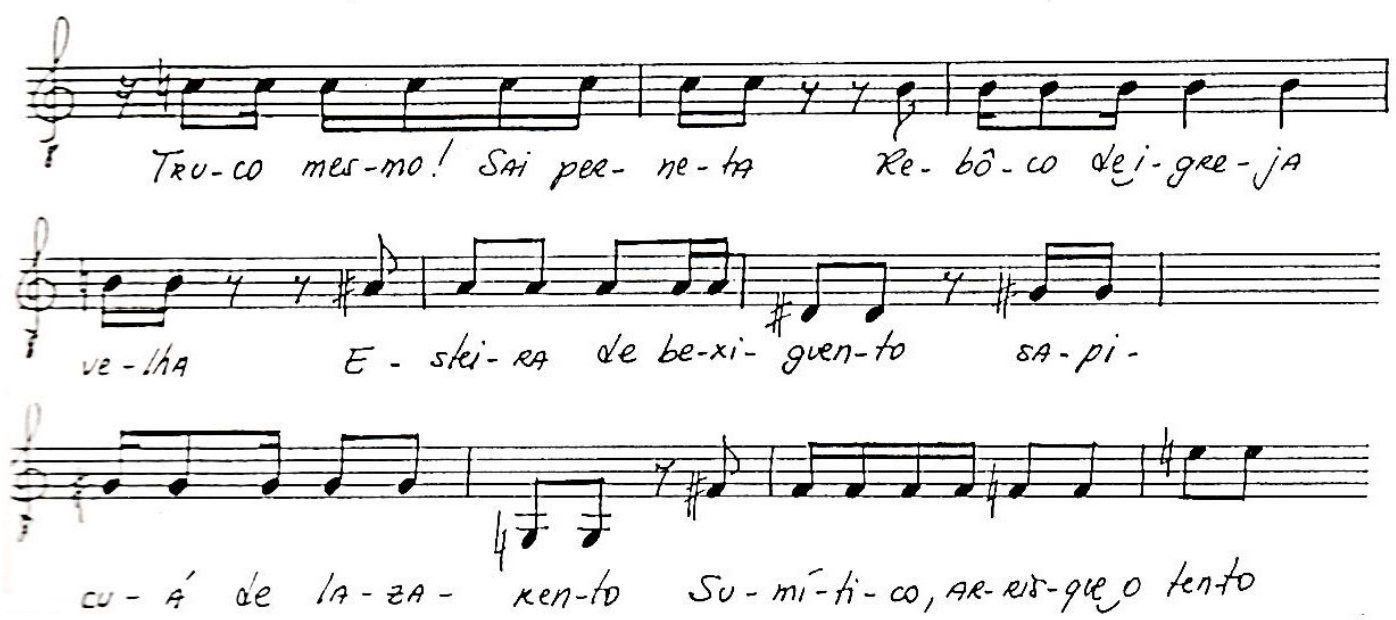

Fig. 5: "Madrigal do truco". Fonte: Arquivo Permanente da Fundação Koellreutter, UFSJ. Ref. BrSjFK-HJK 031 Café.

A melodia do madrigal, que indica um pequeno conjunto coral secular, escapa, no entanto, ao tonalismo ou modalismo que predominam no folclore e no popular, e que se relacionam com a simplicidade que Mário de Andrade associa com a "intenção social" da obra, com a identificação para a qual concorreriam os efeitos e valores sensuais ${ }^{12}$. No poema, o "Madrigal do truco" consiste em cinco quintetos em redondilha maior, um verso muito comum na poesia popular brasileira, elaborados "exclusivamente com

\footnotetext{
12 Mário de Andrade (2013b, p.57) escreve na introdução ao Café: "Não só a lição do enredo tinha de ser fácil, não só os textos claros, mas a música fácil e clara também. Música, não banal como certo melodismo italiano, não baixa e aviltantemente sensual como tanto Massenet e tanto Puccini, mas fácil, franca, popular, que o povo saísse cantando e assobiando na rua". 0 argumento de Mário de Andrade recorda Renato Almeida (1926, p.147-148), para quem "temos ao alcance de nossas mãos um prodigioso material [...]. Não temos que ser modernos a Satie ou a Schoenberg, mas modernos dentro de nossas forças e de nossa sensibilidade".
} 
frases tradicionais", como explica Mário de Andrade (2013b, p.71), o que converge com o interesse pela linguagem vernacular que esteve na origem do madrigal, reiterado pelo acompanhamento musical utilizado por Koellreutter.

Com a intenção de uma obra politicamente engajada, Mário de Andrade compartilha o Café com Francisco Mignone porque o julga apto a representar "a sujeira das impurezas da dor" em detrimento do "grã-finismo purista" da música do XX (ANDRADE, 1942a). Ao discutir a forma da obra em suas cartas a Francisco Mignone, Mário de Andrade conclui que a facilidade constitui um defeito que se torna qualidade, considerando a "intenção social" da obra e a necessidade de simplicidade, principalmente nos "momentos corais mais 'sociais'". Critica Schoenberg e sugere ritmos brasileiros, reiterando a Mignone a possibilidade de ser "atonal se quiser, mas tem de ser popular", argumenta, uma vez que uma "concepção positivamente socialista e de combate humano" rejeita uma solução "individualista e refinada" (ANDRADE, 1942b).

Ao noticiar o desenvolvimento da obra, Mário de Andrade confessa a Mignone: "Nada tive que escrever, lembrei textos tradicionais populares, dos mais conhecidos em todo o Brasil" (ANDRADE, 1942c), aconselhando o uso de ritmos tradicionais, a exemplo da embolada, que define como uma linha de andamento acelerado em que abundam as notas rebatidas em semicolcheias:

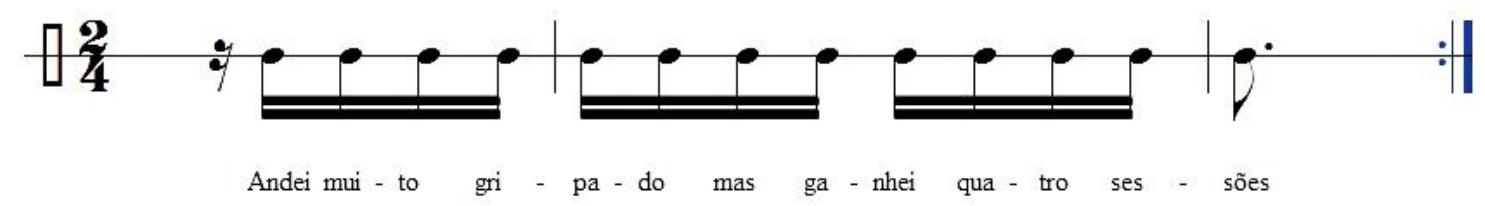

Fig. 6: Embolada. Fonte: Acervo Mário de Andrade, IEB, USP. Ref.: MA-C-CAMMA 341. Carta de 15 de outubro de 1942.

Mignone responde imediatamente a carta de seu correspondente e apresenta sua composição para o tema da "embolada", que constituiria "A embolada da ferrugem", da primeira cena do segundo ato, bem como para o "Quinteto dos serventes", que a antecederia (MIGNONE, 1942). Koellreutter, por sua vez, transforma em sua composição o texto do "deputadinho da ferrugem", previsto como uma embolada, em um discurso puramente oral e sem acompanhamento musical.

Ainda em suas cartas, Mário de Andrade sugere a Mignone a melodia para determinados trechos do poema, indicando um andamento coerente, ou seja, do folclore, como o "Fugato coral" do terceiro ato (ANDRADE, s.d.): 


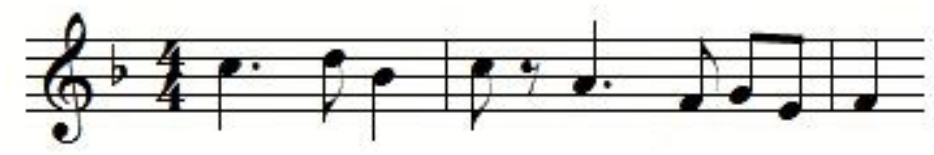

Fo - go e mais fogo! Fo - go até mor - rer!

Fig. 7: "Fugato coral". Fonte: Acervo Mário de Andrade, IEB, USP. Ref.: MA-MMA 211

O autor dos poemas reproduz as mesmas informações e sugestões para o "Grande coral de luta" do mesmo ato:

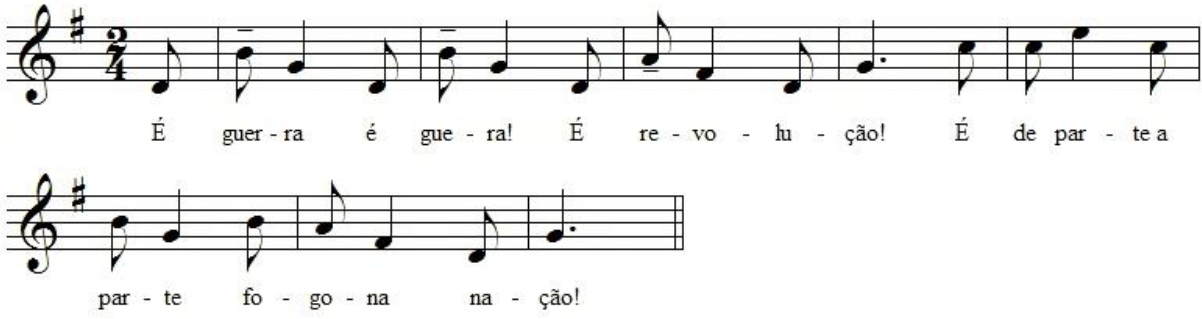

Fig. 8: "Grande coral de luta". Fonte: Acervo Mário de Andrade, IEB, USP. Ref.: MA-MMA 211.

Embora aproveite as indicações de Mário de Andrade para a composição musical, reproduzindo eventualmente os textos com pequenas adaptações e adotando sugestões, Koellreutter não faz concessões quanto às suas concepções musicais, visivelmente divergentes, sobretudo em relação ao emprego do folclore e do popular. Em contraste com as sugestões de Mário de Andrade, com melodias tonais, simples e apelativas, Koellreutter musicaliza o "Fugato coral" com uma melodia atonal, acompanhada pela orquestra, caracterizada não apenas pelo atonalismo, mas pela aleatoriedade ${ }^{13}$, improvisação, aplicação de planimetria, por meio dos diferentes diagramas e simultanoides, definidos como acordes caracterizados pela impossibilidade de classificação pelo tonalismo.

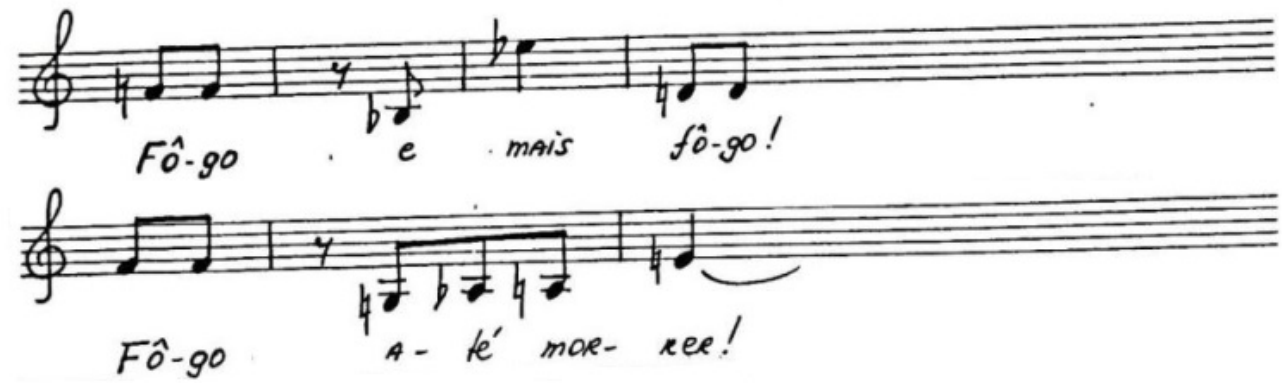

Fig. 9: "Fugato coral". Fonte: Arquivo Permanente da Fundação Koellreutter, UFSJ. Ref. BrSjFK-HJK 031 Café.

O tema do "Fugato coral" se contrapõe, conforme uma composição fugal, com outras vozes corais que entram sucessivamente, defasadas, repetindo o tema, e se dissolvem gradualmente na crescente massa sonora da orquestra. 
Para o "Grande coral de luta", Koellreutter compõe uma homofonia, um coral a quatro vozes:
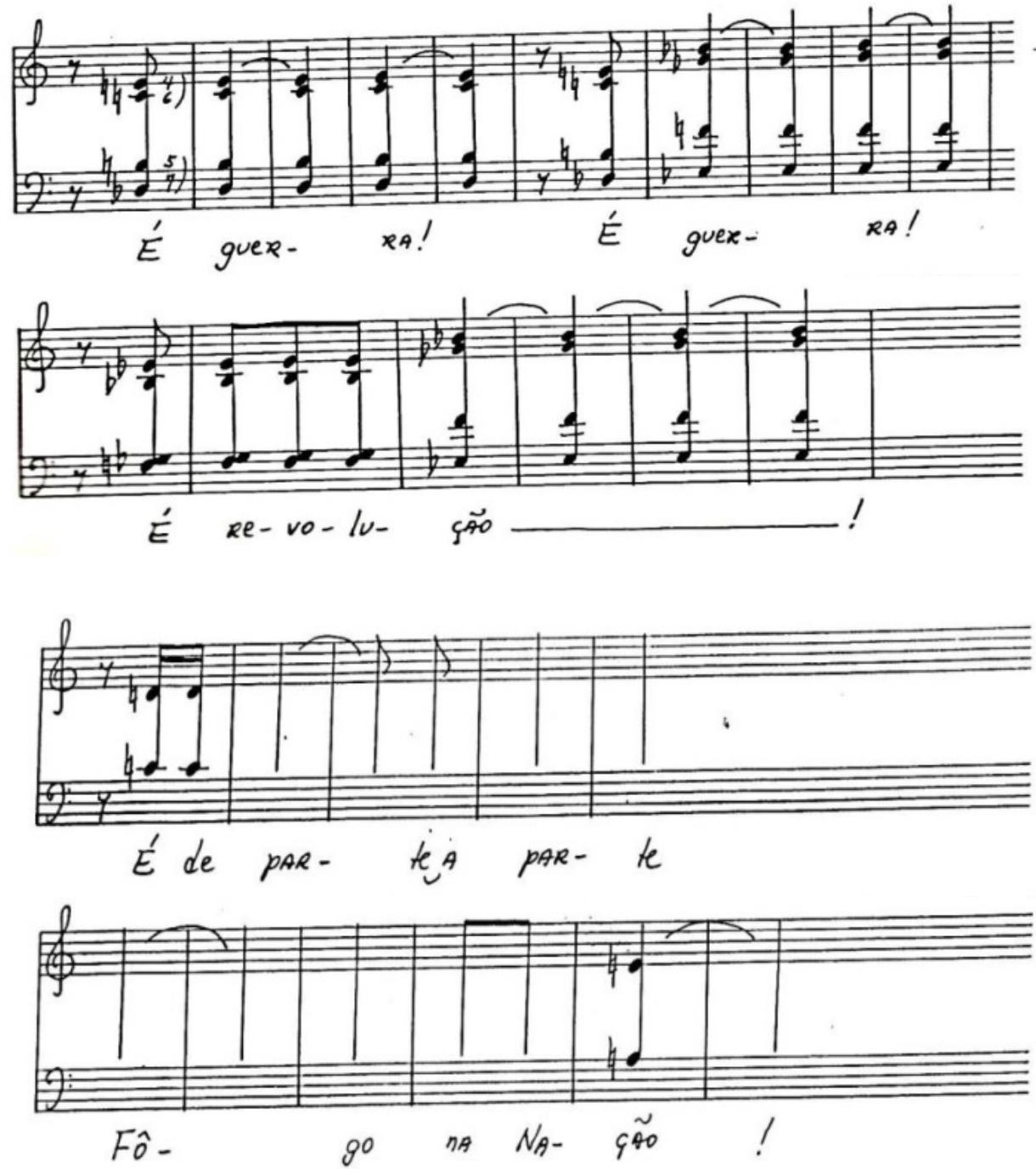

Fig. 10: "Grande coral de luta". Fonte: Arquivo Permanente da Fundação Koellreutter, UFSJ. Ref. BrSjFK-HJK 031 Café.

Ao final do "Grande coral de luta", formado por "grupos em tons diferentes", como indica a partitura, Koellreutter parece realizar a forma e a finalidade coletivistas da obra, "derivada do conceito de coletividade", desejadas por Mário de Andrade (2013b, p.55), ao envolver a participação da plateia, que cantaria a melodia com os grupos corais ${ }^{14}$.

A obra que, para o autor do poema, seria predominantemente composta a partir do folclore, segundo os preceitos de seu nacionalismo musical, adquire, sob a batuta de Koellreutter e os preceitos da "nova arte", a impressão da personalidade e individualidade do artista, ou seja, "algo novo e pessoal" que o compositor acreditava ser inviabilizado pelo folclore. A realização da personalidade na obra de arte constitui um dos conceitos fundamentais para Koellreutter, a raridade, relacionada ao valor de infor-

\footnotetext{
14 Regida por Luis Gustavo Petri, a apresentação em Santos, em dezembro de 1996, não contou com a participação da plateia, como planejado por Koellreutter. Anotações que acompanham as partituras, encontradas na mesma pasta localizada no arquivo do compositor em São João del-Rei, indicam outros procedimentos que envolvem a plateia, como os encartes, que circulariam de acordo com as orientações do regente e seriam executados pelos naipes e pela plateia.
} 
mação, representando a contraparte do conceito de artesanato de Mário de Andrade, na medida em que o raro nomeia aquilo que não se pode ensinar ${ }^{15}$. Assim, o conceito de raridade de Koellreutter converge com o conceito de desnaturalização de Adorno, compreendido como distanciamento contra o condicionamento do ouvido provocado pelo automatismo. E revela, talvez, uma concepção de individualidade apropriada para a sensibilidade requerida pelo liberalismo e, agora, pelo neoliberalismo, e para a racionalidade da prometida globalização, tão divergente da identificação com o povo por meio do folclore e do popular, proposta pelo nacionalismo musical, que desconfia, e com razão, do universalismo ${ }^{16}$.

No seio dos conflitos entre erudito e vanguarda, de um lado, popular e folclore, de outro, a musicalização do poema de Mário de Andrade por Koellreutter parece representar, portanto, o golpe decisivo em sua luta contra as "forças disruptivas" do "nacionalismo exaltado e exasperado" que "separam os homens", como revela sua resposta para a Carta Aberta de Camargo Guarnieri (KOELLREUTTER, 1951 apud KATER, 2001, p.130), afinando o tema da obra com uma linguagem musical apropriada. Mas, ao identificar o tema do poema, a revolução, com o mito, que, para Koellreutter, simboliza a superação do dualismo, o compositor parece transferir o mais fundamental do tema, a luta de classes, para o que compreende como conscientização da realidade atual (enquanto o mito contraditoriamente representa a simultaneidade de opostos como o real e o irreal). O mito, para Koellreutter (1991, p.161), reflete um estado de conscientização que desconhece a contrariedade de opostos e se caracteriza por "uma forma imaginativa de pensamento oposta" ao "pensamento racional" (KOELLREUTTER, 1995, p.8). Segundo Koellreutter (1991, p.162),

Tanto no mito quanto na música o que soa não é decisivo, quando não se leva em consideração o que não soa. De-cisão significa anulação da cisão, anulação daquilo que cinde, separa. Assim no mito, o dito revela e valoriza o não-dito, e o não-dito revela e valoriza o dito, e, na música, o som revela e valoriza o silêncio e o silêncio revela e valoriza o som.

E o autor do poema, assim como os compositores do nacionalismo musical, ao se engajarem na politização da arte, insistem justamente na luta de classes e, portanto, na compreensão da sociedade como conflito permanente como condição fundamental para a democracia. Assim, a musicalização de Koellreutter parece se conciliar com o

\footnotetext{
15 Mário de Andrade (1963, p.13) define o artesanato como "a parte da técnica que se pode ensinar", relacionada ao elemento material da arte. Se nos guiarmos pelos argumentos de Mário de Andrade, Koellreutter pareceria mais interessado pela "parte da técnica de arte que é, por assim dizer, a objetivação, a concretização de uma verdade interior do artista. Esta parte da técnica obedece a segredos, caprichos e imperativos do ser subjetivo, em tudo o que ele é, como indivíduo e como ser social. Isto não se ensina" (ANDRADE, 1963, p.13).

16 Mário de Andrade (1991, p.21), ao comentar a conservação do "estado de subalternidade" das nações colonizadas presente na noção de internacionalismo, conclui que "muitos compositores tardios, ecos preguiçosos desses tempos mais cômodos, escamotearam agora a palavra 'internacionalista', a substituíram por outra, e vêm nos falar cantando de música 'universalista', de 'música universal'. Isto é um verdadeiro primor de ignorância sociológica, pois nem sequer o proletariado urbano, universalista por fatalidade econômica e técnica, já produziu música popular que de qualquer modo se possa dizer universal. E um verdadeiro universalismo étnico é sonho para um futuro por demais remoto, pra que possamos argumentar com ele por enquanto. Sonho, aliás, que nenhuma experiência da história humana pode confirmar. A tal de 'música universal' é um esperanto hipotético, que não existe. Mas existe, não posso negar, a música internacionalista, a granfinagem tediosa e fatigada dos 'Transatlantiques' da comédia célebre".
} 
ideal do "artista verdadeiro" porque livre sonhado por Mário de Andrade (2013a, p.574) em "um futuro mais completado em sua humanidade". Acontece que esse futuro ainda não chegou... e tudo indica que ainda demora a chegar.

\section{Referências}

ADORNO, Theodor W. Filosofia da nova música. São Paulo: Perspectiva, 1989.

ADORNO, Theodor W. Introdução à Sociologia da Música: doze preleções teóricas. São Paulo: Ed. Unesp, 2011.

ADRIANO, Carlos; VOROBOW, Bernardo. A revolução de Koellreutter. Folha Mais! São Paulo, 7 nov. 1999.

ALMEIDA, Renato. História da música brasileira. Rio de Janeiro: Briguiet \& Comp., 1926.

ANDRADE, Mário. [Correspondência]. Destinatário: Francisco Mignone. [S. l.], 5 jun. 1942a. 1 carta. Série Manuscritos Mário de Andrade: Café. Acervo Mário de Andrade, IEB, USP. Ref.: MA-C-CAMMA 343.

ANDRADE, Mário. [Correspondência]. Destinatário: Francisco Mignone. [S. l.], 5 jun. 1942b. 1 carta. Série Manuscritos Mário de Andrade: Café. Acervo Mário de Andrade, IEB, USP. Ref.: MA-C-CAMMA 340.

ANDRADE, Mário. [Correspondência]. Destinatário: Francisco Mignone. [S. l.], 15 out. 1942c. 1 carta. Série Manuscritos Mário de Andrade: Café. Acervo Mário de Andrade, IEB, USP. Ref.: MA-C-CAMMA 341.

ANDRADE, Mário de. O baile das quatro artes. São Paulo: Martins, 1963.

ANDRADE, Mário de. Aspectos da música brasileira. Belo Horizonte; Rio de Janeiro: Villa Rica, 1991.

ANDRADE, Mário de. Poesias completas. Rio de Janeiro: Nova Fronteira, 2013a. v. 1.

ANDRADE, Mário de. Poesias completas. Rio de Janeiro: Nova Fronteira, 2013b. v. 2.

ANDRADE, Mário de. [Correspondência]. Destinatário: Francisco Mignone. [S. l., s. d.]. 1 carta. Série Manuscritos Mário de Andrade: Café. Acervo Mário de Andrade, IEB, USP. Ref.: MA-MMA 211.

ANTELO, Raúl. Na ilha de Marapatá: Mário de Andrade lê os hispano-americanos. São Paulo: Hucitec; Brasília: INL, Fundação Nacional Pró-Memória, 1986, p. 100. 
BARBARA, Danusa. Koellreutter. Jornal do Brasil, Rio de Janeiro, 1 nov. 1975, p. 5.

BREUNIG, T. H. Um ensaio inacabado: o projeto de musicalização de Macunaíma. Boletim de Pesquisa NELIC, Florianópolis, Achados no arquivo, v. 16, n. 25, 2016.

FERNANDES, Florestan. Mário de Andrade e o folclore brasileiro. Revista do Instituto de Estudos Brasileiros, São Paulo, n. 36, p. 141-158, 1994.

GANDELMAN, Saloméa. Prefácio. In: KOELLREUTTER, H.-J. Estética. São Paulo: Novas Metas, 1983.

GRAMSCl, Antonio. Cuadernos de la cárcel: literatura e vida nacional. 3. ed. México, D.F.: Juan Pablos, 1998.

GUARNIERI, Rossine Camargo. Koellreutter, charlatão e plagiário. Fundamentos, São Paulo, n. 28, p. 26-28, jun. 1952.

GUERRA-PEIXE. Música e dodecafonismo. Fundamentos, São Paulo, n. 29, p. 3, 1952.

GUERRA-PEIXE. Que ismo é esse, Koellreutter? Fundamentos, São Paulo, n. 31, p. 3335, 1953.

KATER, Carlos Elias. Música Viva e H.J. Koellreutter: movimentos em direção à modernidade. São Paulo: Musa; Atravez, 2001.

KOELLREUTTER, H.-J. [Correspondência]. Destinatário: Mário de Andrade. [S. l.], set. 1942. 1 cartão de visitas, 1 carta-convite. Acervo Mário de Andrade, IEB, USP. Ref.: MAC-CPL 3801.

KOELLREUTTER, H.-J. Artistas modernos. Leitura, Rio de Janeiro, n. 19, p. 57, jun. 1944a.

KOELLREUTTER, H.-J. Música sacra e música nova. Leitura, Rio de Janeiro, n. 14, p. 47, fev. 1944b.

KOELLREUTTER, H.-J. Panamericanismo musical. Leitura, Rio de Janeiro, n. 14, p. 47, fev. 1944 c.

KOELLREUTTER, H.-J. Sobre "O Banquete" de Mário de Andrade. Leitura, Rio de Janeiro, n. 27, p. 53-54, mar. 1945.

KOELLREUTTER, H.-J. Contestando afirmações infundadas. Leitura, Rio de Janeiro, n. 39, p. 53-54, abr. 1946a. 
KOELLREUTTER, H.-J. O "Lied" Brasileiro. Leitura, Rio de Janeiro, n. 39, p. 38, abr. $1946 b$.

KOELLREUTTER, H.-J. Reparos e reflexões. Leitura, Rio de Janeiro, n. 40, p. 59-61, maio/jun. 1946c.

KOELLREUTTER, H.-J. Arte funcional: a propósito de "O Banquete" de Mário de Andrade. Fundamentos, São Paulo, n. 1, p. 148-151, jun. 1948.

KOELLREUTTER, H.-J. Terminologia de uma nova estética da música. Porto Alegre: Movimento, 1990.

KOELLREUTTER, H.-J. Mito como silêncio: premissa de uma estética musical que tende a superar o dualismo. In: SCHÜLER, Donaldo; GOETTEMS, Miriam B. (org.). Mito ontem e hoje. Porto Alegre: Ed. UFRGS, 1991.

KOELLREUTTER, H.-J. A caminho da superação dos opostos. Música hoje: Revista de Pesquisa Musical, CPMC, UFMG, Belo Horizonte, v. 2, 1995.

KOELLREUTTER, H.-J. Contraponto modal do século XVI: Palestrina. Brasília: Musimed, 1996.

LACLAU, Ernesto; MOUFFE, Chantal. Hegemonía y estrategia socialista: hacia uma radicalización de la democracia. Madrid: Siglo XXI, 1987.

LACLAU, Ernesto. La razón populista. Buenos Aires: Fondo de Cultura Económica, 2011.

MARTINO, Ernesto de. El folclore progresivo y otros ensayos. Trad. Carles Feixa. Barcelona: MACBA, 2008.

MIGNONE, Francisco. [Correspondência]. Destinatário: Mário de Andrade. [S. l.], 18 out. 1942. 1 carta. Série Manuscritos Mário de Andrade: Café. Acervo Mário de Andrade, IEB, USP. Ref.: MA-MMA 21.

NEVES, José Maria. Música contemporânea brasileira. São Paulo: Ricordi, 1981.

ORTIZ, Renato. Cultura brasileira e identidade nacional. 2. ed. São Paulo: Brasiliense, 1986.

PIMENTA, Emanuel Dimas de Melo. Hans Joaquim Koellreutter: as revoluções musicais de um mestre zen. [S. l.: s. n.], 2010. 
SANTORO, Claudio. Problema da Música Contemporânea Brasileira em face das Resoluções e Apelo do Congresso de Compositores de Praga. Fundamentos, São Paulo, n. 3, p. 233-240, jun. 1948.

SILVA, Flávio (org.). Camargo Guarnieri: o tempo e a música. São Paulo: Funarte; Imprensa Oficial, 2001.

VALLS, Alvaro L. M. Estudos de estética e filosofia: numa perspectiva adorniana. Porto Alegre: UFRGS, 2002. 